\title{
Very Bright Europium Complexes that Stain Cellular Mitochondria
}

\author{
James W. Walton $^{b}$, Adrien Bourdolle ${ }^{a}$, Stephen J. Butler ${ }^{b}$, Marine Soulie ${ }^{c}$, Martina Delbianco ${ }^{b}$, Brian \\ K. McMahon ${ }^{b}$, Robert Pal ${ }^{b}$, Horst Puschmann ${ }^{b}$, Jurriaan M. Zwier ${ }^{c}$, Laurent Lamarque ${ }^{c}$, Olivier \\ ${ }_{5}$ Maury* $^{a}$, Chantal Andraud ${ }^{a}$ and David Parker ${ }^{* b}$
}

Received (in Cambridge, XXX) Xth July 2012, Accepted Xth XXXXXXXXX 2012

DOI: 10.1039/b000000x

The synthesis, structure and photophysical properties of a series of highly emissive europium complexes is reported. ${ }_{10}$ Certain complexes enter mammalian cells by macropinocytosis and stain the mitochondria selectively, allowing observation of the Eu emission in cellulo by timegated spectral imaging.

Emissive lanthanide complexes for use as tags in bioassays or as 15 optical probes require both a high emission quantum yield and large molar absorptivity at an excitation wavelength in the range 337 to $405 \mathrm{~nm}$ to give high brightness, $B$, where $B=\varepsilon . \phi .{ }^{1}$ Using sensitised emission, the incorporation of multiple chromophores into a polydentate ligand has been studied, allowing efficient 20 energy transfer to a bound $\mathrm{Eu}(\mathrm{III})$ ion that is efficiently shielded from vibrational deactivation by solvent. ${ }^{2}$ In aqueous media, no 1:1 [Eu.L] systems have been reported with a brightness $\left(\lambda_{\mathrm{exc}}>\right.$ $337 \mathrm{~nm}$ ) exceeding $3000 \mathrm{M}^{-1} \mathrm{~cm}^{-1}$.

Here, we report systems in which the brightness is an 25 order of magnitude larger. Moreover, certain complexes are taken into mammalian cells, allowing their use in microscopic imaging. In designing these systems, we have combined the very effective shielding of the Eu(III) ion using nonadentate ligands based on triazacyclononane ${ }^{3,4}$ with strongly absorbing $p$-substituted aryl-

30 alkynyl groups, [EuL ${ }^{1-4}$ ]. ${ }^{5}$ Both carboxylate and phosphinate substituted systems have been prepared ${ }^{6}$, and the synthetic pathway allows the preparation of derivatives that can be conjugated to a vector. In the phosphinate systems, ${ }^{3}$ the phosphorus substituents adopt a common configuration in the 35 complex, and more effectively shield the excited Ln ion from intermolecular quenching processes.

The ligands and their Eu complexes were prepared using established methods. ${ }^{6}$ In the case of $\left[\mathrm{Eu} . \mathrm{L}^{2 \mathrm{C}}\right.$ ], the third substituent, bearing a remote protected amine group, was 40 introduced last, following stepwise alkylation and de-protection of mono-BOC-triazacyclononane ${ }^{6}$. Crystals of [Eu.L ${ }^{2 a}$ ] grew from aqueous methanol and the structure of $\left[\mathrm{Eu} . \mathrm{L}^{2 \mathrm{a}}\right]$ revealed that the Eu ion is encapsulated by the ligand in a tricapped trigonal prismatic array (Figure 1). The nearest waters are over $6 \AA$ from
45 the metal ion, and the complex is slightly distorted from $C_{3^{-}}$ symmetry. This distortion may be related to the presence of several disordered solvent molecules in the lattice.

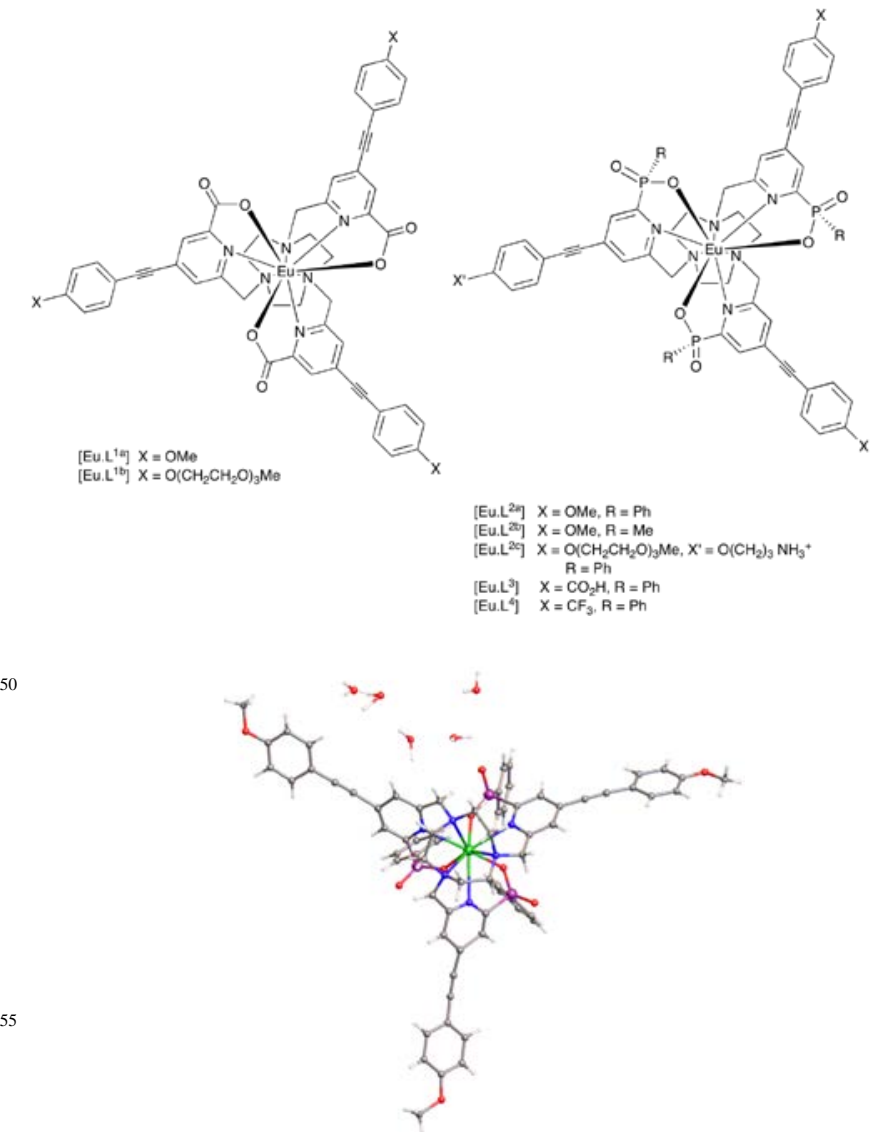

Figure 1 Molecular structure of the europium complex [Eu. $\mathrm{L}^{2 a}$ ] $(120 \mathrm{~K})$ showing part of the hydration sphere; mean bond lengths $( \pm 0.02 \AA)$ are: Eu-N(ring) $2.68 \AA$; Eu-N(py) $2.66 \AA ̊$; Eu-0 $2.32 \AA$. 60 Nearest waters are $\mathrm{H}$-bonded to each $\mathrm{P}=0$, with an average $\mathrm{O}-\mathrm{O}$ distance of $2.66 \AA$ А CCDC 857545. 
This complex, in common with the other triphosphinate systems, exists as a 50:50 mixture of $\Delta-(S S S)$ and $\Lambda$-(RRR) isomers. In solution, one ${ }^{31} \mathrm{P}$ NMR resonance is observed; the paramagnetically shifted ${ }^{1} \mathrm{H}$ NMR spectra of each Eu complex 5 are consistent with average $C_{3}$-symmetry.

Table 1 Selected photophysical data $^{\mathrm{c}}$ for Eu(III) complexes (295K, $\mathrm{MeOH}$, or as stated)

\begin{tabular}{|c|c|c|c|c|}
\hline Complex & $\lambda_{\max } / \mathrm{nm}$ & $\varepsilon / \mathrm{mM}^{-1} \mathrm{~cm}^{-1}$ & $\phi_{\mathrm{em}} / \%$ & $\tau / \mathrm{ms}$ \\
\hline & & & & \\
\hline [Eu.L1a] & 338 & 58.0 & 48 & 0.95 \\
\hline [Eu.L $\left.L^{1 b}\right]$ & 338 & 55.0 & 25 & 1.06 \\
\hline [Eu.Le] & 332 & 58.0 & 52 & 1.30 \\
\hline$\left[E u . L^{2 b}\right]^{a}$ & 331 & 58.1 & 39 & 1.03 \\
\hline$\left[\mathrm{Eu} . \mathrm{L}^{2 \mathrm{c}}\right]^{\mathrm{b}}$ & 332 & 60.0 & 54 & 1.00 \\
\hline$\left[\mathrm{Eu} . \mathrm{L}^{3}\right]$ & 322 & 59.2 & 37 & 1.24 \\
\hline$\left[\mathrm{Eu} . \mathrm{L}^{4}\right]$ & 307 & 63.5 & 15 & 1.35 \\
\hline
\end{tabular}

a in water; in $\mathrm{MeOH} \phi_{\mathrm{em}}=43 \%$ and $\tau=1.18 \mathrm{~ms}$; ${ }^{\mathrm{b}}$ in 3:1 $\mathrm{H}_{2} \mathrm{O} / \mathrm{MeOH} ;{ }^{\mathrm{c}}$ 20 errors on quantum yields and lifetimes are $\pm 15 \%$; at $77 \mathrm{~K}$, phosphorescence spectra for $\left[G d . L^{1 b}\right.$ ] and $\left[G d . L^{2 b}\right.$ ] reveal a broad emission at 390 and 380 $\mathrm{nm}$ respectively, consistent with a dominant charge transfer excitation band ${ }^{5 a}$; d lifetime values in deuteriated solvents were typically 0.2 to $0.3 \mathrm{~ms}$ longer, e.g. for [Eu. $\mathrm{L}^{2 \mathrm{c}}$ ], $\tau\left(\mathrm{D}_{2} \mathrm{O}\right)$ was $1.28 \mathrm{~ms}$, 25 consistent with a metal solvation state, $q=0$.

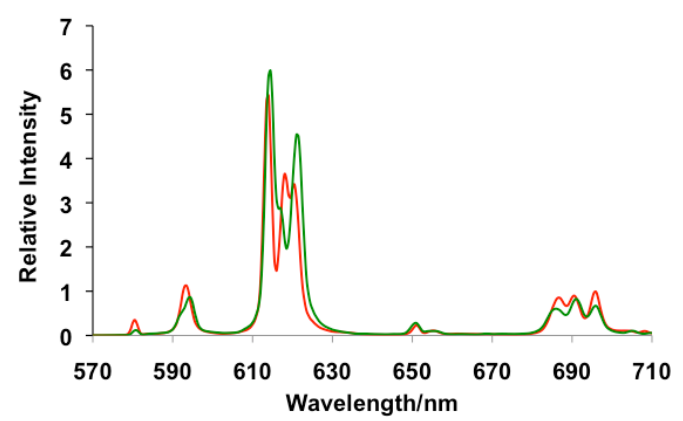

30 Figure 2: Europium emission spectra of [Eu.L $L^{1 a}$ (green) and [Eu.L $\left.L^{2 b}\right]$ (295K, $\mathrm{H}_{2} \mathrm{O}, \lambda_{\text {exc }} 355 \mathrm{~nm}$ ), showing minor changes in spectral form in the hypersensitive $\Delta J=2$ manifold around $615 \mathrm{~nm}$, associated with variation of oxygen donor polarisability.

35 Each chromophore absorbs around 310 to $340 \mathrm{~nm}$, with an overall extinction coefficient of 55-60,000 $\mathrm{M}^{-1} \mathrm{~cm}^{-1}$ (Table). Emission spectra in aqueous or methanol solutions were very similar for each Eu complex (Figure 2). The Eu complexes of $\mathrm{L}^{1 \mathrm{a}}$, $\mathrm{L}^{2 \mathrm{a}}, \mathrm{L}^{3}$ and $\mathrm{L}^{4}$ dissolved readily in $\mathrm{MeOH}$, but were not soluble in 40 water. The water solubility was higher with the complexes bearing PEG substituents, but did not allow greater than $2 \mu \mathrm{M}$ solutions to be made up; for the PMe phosphinate complex, $\left[\right.$ Eu. $\left.\mathrm{L}^{2 \mathrm{~b}}\right]$, the limiting solubility was about $20 \mu \mathrm{M}$. A very intense set of $\Delta J=2$ transitions was observed around 610-620 nm, and 45 the spectral form was consistent with $\mathrm{C}_{3}$-symmetry. Overall emission quantum yields ranged from $15-54 \%$, with the lower values for the $p-\mathrm{CF}_{3}$ substituted complex, [Eu. $\mathrm{L}^{4}$ ] presumably reflecting a less efficient intramolecular energy transfer step.

Following incubation of $\left[\mathrm{Eu} . \mathrm{L}^{2 \mathrm{~b}}\right](10 \mathrm{mM}, 30 \mathrm{~min})$ in the 50 growth medium of NIH-3T3 (mouse skin fibroblasts), $\mathrm{CHO}$ (Chinese hamster ovarian) or PC-3 (human prostate cancer) cells, staining of the cell could be observed by confocal fluorescence microscopy. The cell images (Figure 3) revealed selective staining of the mitochondria, confirmed by co-localisation 55 experiments with Mitotracker Green ${ }^{\mathrm{TM}}$, (ESI). Spectral imaging of washed cells, using time-gated methods, showed the characteristic europium spectral signature, confirming internalization of the intact complex. The europium complexes bearing PEG groups, were not internalized by live mammalian 60 cells.
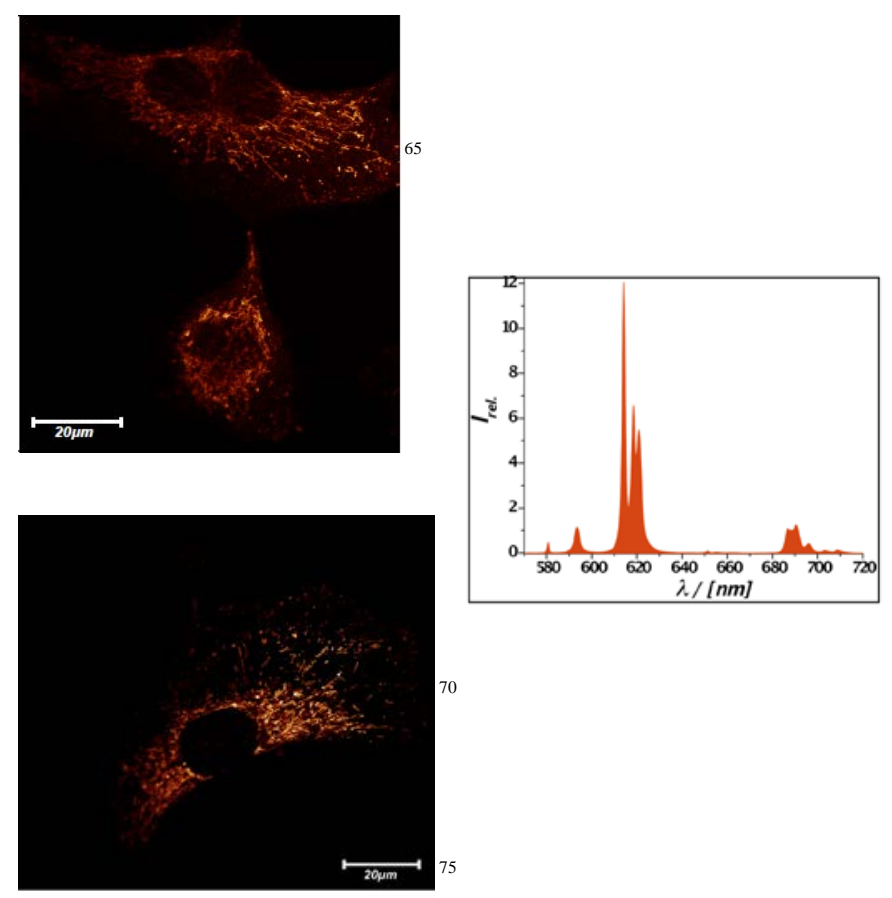

FIGURE 3: left: Bidirectional confocal microscopy images (Leica SP5 II) showing staining of cellular mitochondria in NIH 3T3 cells for $80\left[\right.$ Eu.L $\left.{ }^{2 b}\right]\left(10 \mu \mathrm{M}, 15 \mathrm{~min}\right.$ loading time, $\lambda_{\text {exc }} 355 \mathrm{~nm}, 100 \mathrm{~Hz}$ scan, hybrid detector $600-720 \mathrm{~nm}, 0.77 \mu \mathrm{m}^{3}$ voxel size, $12 \mathrm{~mW}$ laser power, $40 \mathrm{~s}$ image acquisition time); right: time-gated spectral image of a cell $\left(\lambda_{\text {exc }}\right.$ $365 \mathrm{~nm}, t_{\text {int }} 2 \mathrm{~ms}, t_{\text {gate }} 10 \mu \mathrm{s}, 10,000$ scans averaged duty cycle using a 2D CCD detector, 100s acquisition time). The upper image shows a 85 dividing cell $(\mathrm{bar}=20 \mu \mathrm{M})$.

Cell uptake was inhibited (>30\%) by pre-administration for 30 minutes with amiloride $(3 \mathrm{mM})$ or wortmannin $(0.3 \mu \mathrm{M})$, or by lowering the temperature to $5^{\circ} \mathrm{C}$. Such behaviour is consistent with cell uptake by macropinocytosis, as revealed recently for a 90 wide range of emissive lanthanide complexes bearing heterocyclic sensitizing groups. ${ }^{7}$ The lack of uptake of [Eu.L ${ }^{1 b}$ ] and $\left[E u . L^{2 c}\right.$ ] may reflect inhibition of a cell surface protein binding step that is essential for macropinocytosis. Using a standard MTT assay, assessing perturbation of mitochondrial 95 redox activity, the $\mathrm{IC}_{50}$ value was calculated to be $>150 \mu \mathrm{M}$ for $\left[\right.$ Eu. $\left.\mathrm{L}^{2 \mathrm{~b}}\right]$. The amount of complex internalized was estimated by ICP-MS analysis of intracellular Eu, for a set of 390,000 washed and counted cells, revealing the complex concentration within the 
cell to be $0.65( \pm 0.3) \mu \mathrm{M}$ for a $10 \mu \mathrm{M}$ loading, under the stated conditions. ${ }^{8}$

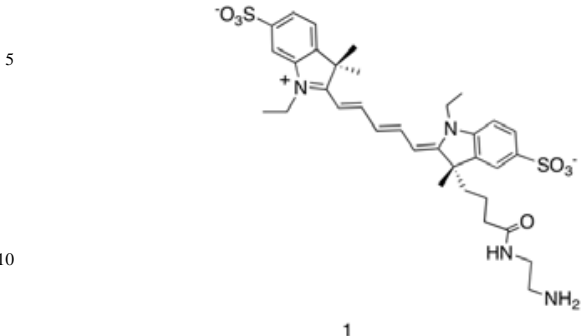

Furthermore, these Eu complexes can act as effective donors to near-IR acceptor dyes, such as the cyanine dye, $\mathbf{1}$, allowing their 15 use in time-resolved homogeneous FRET assays. ${ }^{9}$ A short comparative analysis of the efficiency of energy transfer was undertaken, comparing the behaviour of [Eu.L $\left.{ }^{1 a}\right]$, [Eu.L $\left.{ }^{2 a}\right]$ and [Eu. $\mathrm{L}^{2 \mathrm{~b}}$ ] in $\mathrm{MeOH}$ and 1:1 aqueous methanol. The quenching of the $\mathrm{Eu}$ emission was monitored as a function of added dye 20 concentration over the range 0.3 to $5 \mu \mathrm{M}$, using $5 \mu \mathrm{M}$ solutions of the Eu complex. The second order rate constants characterizing intermolecular energy transfer were $1.45,0.57$ and $0.65 \mathrm{mM}^{-1} \mathrm{~s}^{-1}$ associated with Forster radii of 6.86, 6.95 and $6.76 \mathrm{~nm}$ respectively. ${ }^{10}$ The lower efficiency of quenching with each 25 phosphinate complex may reflect both the slightly larger spectral overlap integral in [Eu.L ${ }^{1 \mathrm{a}}$ ] (Figure 3: $\Delta J=2$ manifold is about $10 \%$ larger for [Eu.L $L^{1 \mathrm{a}}$ ] vs [Eu. $\left.\mathrm{L}^{2 \mathrm{a} / 2 \mathrm{~b}}\right]$ ), as well as the different electric dipole transition moments in the complexes.

30 In conclusion, the europium complexes defined here possess a brightness that lies in the range 15,000 to $30,000 \mathrm{M}^{-1} \mathrm{~cm}^{-1}$ at 337 $\mathrm{nm}$, auguring well for a role as donors in FRET bio-assays and as 2-photon probes. ${ }^{4 a}$ An example is presented of cell uptake by macropinocytosis leading to selective mitochondrial staining; the 35 very high brightness aids rapid spectral imaging. This behaviour paves the way for examination of analogues as intracellular optical probes, in which the emission spectral signature is a function of a biochemical variable, such as $\mathrm{pH}$, bicarbonate or related bioactive species. ${ }^{11}$ Furthermore, these examples highlight 40 the opportunities to develop emissive metal coordination complexes as more general stains and probes for the biosciences. 12

We thank the EPSRC, ESF COST CM-1006 and the ERC (DP) for support (FCC 266804).

45

\section{Notes and references}

${ }^{a}$ University of Lyon 1, ENS Lyon, CNRS - UMR 5182, 46 Allée d'Italie 69364 Lyon, France; E-mail : olivier.maury@ens-lyon.fr

${ }^{b}$ Department of Chemistry, Durham University, South Road, Durham, 50 DH1 3LE, UK. Fax: +44-191-3844737; Tel: +44-191-3342033; E-mail:

david.parker@dur.ac.uk

${ }^{c}$ Cisbio Bioassays, Parc Marcel Boiteux, BP 84175, 30200 Codolet, France

$\dagger$ Electronic Supplementary Information (ESI) available: Details of 55 complex synthesis and characterization, microscopy/spectroscopy

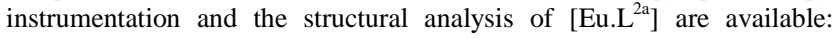
CCDC 857545. For ESI and crystallographic data in CIF or other electronic format see DOI: 10.1039/b00000x/
1. Reviews: (a) C. P. Montgomery, E. J. New, R. Pal, D. Parker, Acc. Chem. Res. 2009, 42, 925. (b) E. G. Moore, A. P. S. Samuel, K. N. Raymond, Acc. Chem. Res. 2009, 42, 542. (c) S. V. Eliseeva, J.-C. G. Bunzli, Chem. Soc. Rev. 2010, 39, 189.(d) S. Faulkner, S. J. A. Pope, B. P. Burton-Pye, Appl. Spectrosc. Rev. 2004, 40, 1. (e) Y. Ma, Y. Wang, 65 Coord. Chem. Rev. 2010, 254, 972.

2. Selected examples of sensitized europium emission, in protic media with excitation in the range 337 to $405 \mathrm{~nm}$ : (a) R. A. Poole, G. Bobba, M. J. Cann, J.-C. Frias, D. Parker, R. D. Peacock, Org. Biomol. Chem. 2005 , 3, 1013. (b) S. Petoud, G. Muller, E. G. Moore, J. Xu, J. Sokolnicki, J. P. 70 Riehl, U. N. Le, S. M. Cohen, K. N. Raymond, J. Am. Chem. Soc. 2007, 129, 77. (c) M. Starck, P. Kadjane, E. Bois, B. Darbouret, A. Incamps, R. Ziessel, L. J. Charbonniere, Chem. Eur. J. 2011, 17, 9164. (d) P. A. Atkinson, K. S. Findlay, F. Kielar, R. Pal, D. Parker, R. A. Poole, H. Puschmann, S. L. Richardson, P. A. Stenson, A. L. Thompson, J. Yu, 75 Org. Biomol. Chem. 2006, 4, 1707. (e) E. S. Andreiadis, R. Demadrille, D. Imbert, D. Pecaut, M. Mazzanti, Chem. Eur. J. 2009, 15, 9458. (f) C. P. Montgomery, E. J. New, L-O. Palsson, D. Parker, A. S. Batsanov, L. Lamarque, Helv. Chim. Acta, 2009, 92, 2186. (g) N. Maindron, S. Poupart, M. Hamon, J-B. Langlois, N. Ple, L. Jean. A. Romieu, P-Y. 80 Renard, Org. Biomol. Chem. 2010, 9, 2357. (h) A-S. Chauvin, S. Comby, C. D. B. Vandevyver, B. Song, J.-C. G. Bunzli, Chem. Eur. J. 2008, 14 1726.

3. (a) J. W.Walton, R. Carr, N.H. Evans, A. M. Funk, A. M. Kenwright, D. Parker, D. S. Yufit, M. Botta, S. De Pinto, K-L.Wong, 85 Inorg. Chem. 2012, 51, in press, doi.org/10.021/ic300147p. (b) J. W. Walton, L. De Bari, G. Pescitelli, H. Puschmann, D. S. Yufit, Chem. Commun. 2011, 47, 12289.

4. Polydentate ligands based on triazacyclononane with picolinate donors: (a) A. D’Aléo, A. Bourdolle, S. Bulstein, T. Fauquier, A. 90 Grichine, A. Duperray, P. L. Baldeck, C. Andraud, S. Brasselet, O. Maury Angew. Chem. In. Ed. 2012 in press; (b) C. Gateau, M. Mazzanti, J. Pecaut, F. A. Dunand, L. Helm, Dalton Trans. 2003, 2428; (c) G. Nocton, A. Nonat, C. Gateau, M. Mazzanti, Helv. Chem. Acta 2009, 92, 2257; (d) M. Giraud, E. S. Andreiadis, A. S. Fisyuk, A. Demadrille, J. Pecaut, D. 95 Imbert, M. Mazzanti, Inorg. Chem. 2008, 47, 3952; (e) A. Nonat, C. Gateau, P. H. Fries, M. Mazzanti, Chem. Eur. J. 2006, 12, 7133. (f) J. Hovinen, P. M. Guy, Bioconjugate Chem. 2009, 20, 404; (g) H. Takalo, I. Hemmila, T. Sutela, M. Latva, Helv. Chim. Acta 1996, 79, 789.

5. Recent examples of the use of aryl-alkynylpyridines as sensitizing 100 groups for Eu emission: (a) A. D’Aléo, A. Picot, A. Beeby, J. A. G. Williams, B. Le Guennic, C. Andraud, O. Maury, Inorg. Chem. 2008, 47, 10258. (b) A. D’Aléo, A. Picot, P. L. Baldeck, C. Andraud, O. Maury, Inorg. Chem. 2008, 47, 10269. (c) H. K. Kong, F. L. Chadbourne, G.-L. Law, C. Y. T. Ko, H. L. Tam, S. L.Cobb, C. K. Lau, C. S. Lee, K-L. 105 Wong Chem. Commun. 2011, 47, 8052; (d) A. Bourdolle, M. Allali, J.-C. Mulatier, B. Le Guennic, J. Zwier, P. L. Baldeck, J.-C. G. Bünzli, C. Andraud, L. Lamarque, O. Maury, Inorg. Chem. 2011, 50, 4987.

6. Details of complex synthesis and characterization are given in the supporting information.

110 7. E. J. New, A. Congreve, D. Parker, Chem. Sci. 2010, 1, 111.

8. Similar methods have been reported earlier, ${ }^{2 \mathrm{~h}, 7}$ and in J. Yu, R. Pal, D. Parker, R. A. Poole, M. J. Cann, J. Am. Chem. Soc. 2006, 128, 2294.

9. E. Trinquet, M. Fink, H. Bazin, F. Grillet, F. Maurin, E. Bourrier, H. Ansanay, C. Leroy, A. Michaud, T. Durroux, D. Maurel, F. Malhaire, C. 115 Goudet, J.-P.Pin; M. Naval, O. Hernout, F. Chretien, Y. Chapleur, G. Mathis, Anal. Biochem. 2006, 358, 126.

10. In the rapid diffusion limit, energy transfer from a Eu donor to the dye acceptor (Q) obeys pseudo-first order kinetics, where $1 / \tau_{0}=\mathrm{k}_{0} ; 1 / \tau=$ $\mathrm{k}_{\mathrm{obs}}$ and $\mathrm{k}_{\mathrm{obs}}=\mathrm{k}_{\mathrm{o}}+\mathrm{k}_{2}[\mathrm{Q}]$; hence $\tau_{0} / \tau=\mathrm{k}_{\mathrm{obs}} / \mathrm{k}_{\mathrm{o}}=1+\mathrm{k}_{2} / \mathrm{k}_{\mathrm{o}}[\mathrm{Q}]$. 120 Hence the slope of the plot of $\tau_{0} / \tau$ vs [Q] is $\mathrm{k}_{2} / \mathrm{k}_{0}$, allowing the second order rate constant for energy transfer, $\mathrm{k}_{2}$, to be estimated; C. F. Meares, T. G. Wensel, Acc. Chem. Res. 1984, 17, 202.

11. For an example of this approach using a Eu complex with an azaxanthone sensitizer to monitor bicarbonate levels in mitochondria: D. 125 G. Smith,G-L. Law, R. Pal, D. Parker, K-L. Wong, Chem. Commun. 2011, 47, 7347; D. G. Smith, R. Pal, D. Parker, Chem. Eur. J. 2012, in press, doi.10.1002/chem.201201738.

12. Examples of the use of emissive complexes of the d-block elements, e.g. Re, Pt, Ir, are increasingly common; e.g. F. L. Thorp${ }_{130}$ Greenwood, M. P. Coogan, L. Mishra, N. Kumari, G. Rai and S. Saripella, New J. Chem., 2012, 36, 64. 